\title{
Secretion of byssal threads and attachment strength of Mytilus galloprovincialis: the influence of size and food availability
}

\author{
JOSE M.F. BABARRO, MARÍA JOSÉ FERNÁNDEZ REIRIZ AND UXÍO LABARTA \\ Instituto de Investigaciones Marinas CSIC, Eduardo Cabello 6, 36208 Vigo, Spain
}

\begin{abstract}
Byssogenesis rate and attachment strength of the mussel Mytilus galloprovincialis were investigated in the laboratory considering different body sizes and feeding conditions. Byssal thread secretion was significantly higher in juveniles as compared to larger mussels of approximately $87 \mathrm{~mm}$ shell length. Asymptotic number of threads attached was obtained from approximately 72 hours onwards within a range of 42-46 and 27-31 for juveniles and larger experimental mussels, respectively $(P<0.05$ ANOVA). Absorption efficiency values of control fed individuals dropped significantly from 0.78 in juveniles to 0.70 in larger mussels $(P<0.001$ ANOVA) which pointed out energetic constraints of mussels with regard to their size and its probable effect on byssus secretion rates. Attachment force was 2.8 times higher in larger mussels than in juveniles (2.21 versus $0.78 \mathrm{~N}$ for both sizes, respectively; $P<0.001$ ANOVA) which in turn followed the same order of magnitude than differences in the thread's thickness values of both experimental mussel sizes. Tenacity followed a reverse pattern with juveniles presenting two-fold higher values than larger mussels $(P<0.001$ ANOVA) based on a lower increment of attachment force (x2.8) as compared to shell area (x6) for the comparison larger versus juvenile mussel size, which in turn might suggest that larger specimens secreted weaker threads. When animals were maintained unfed for a week, a significant drop in both byssus secretion and attachment force were observed in juveniles but was not the case for larger mussels most likely as a consequence of a relatively short period of maintenance under food availability stress for the latter individuals that showed significantly higher initial condition and/or energetic store values. Accordingly, the use of energetic reserves in juveniles kept unfed for a week together with a significant drop in byssus secretion and attachment force might suggest a link, i.e. transfer of energy between soft tissues and byssus under stress. Quantitative values of byssal threads, based on the significance of the byssus versus attachment force relationship, together with its morphometric value, i.e. thread's thickness, represented a primary mechanism to explain variability in attachment strength of $\mathrm{M}$. galloprovincialis of the different body sizes studied here.
\end{abstract}

Keywords: Mytilus galloprovincialis, byssogenesis, attachment strength, body size

Submitted 19 June 2006; accepted 14 December 2007

\section{INTRロロUCTIDN}

Sessile mussels attach to the substratum by byssal threads that ensure a structure to withstand drag and avoid dislodgement in their environment. Byssal threads are formed within the groove of the mussel foot and the strength of the byssal attachment is a function of both mechanical and biochemical properties of threads secreted. Byssogenesis of different species of the Mytilus genus has been described to vary with a large number of factors, i.e. temperature (Allen et al., 1976), salinity and water velocity (Van Winkle, 1970), agitation (Young, 1985), oxygen tension (Widdows \& Bayne, 1971), wave action associated to Atlantic winds (Price, 1982), circadian and tidal rhythms (Martella, 1974) among others. Body size of individuals, however, as an important endogenous factor has been much less investigated. Although mussel size has been reported to exert significant incidence on byssogenesis, different studies have shown an unclear general pattern (see review of Clarke \& McMahon, 1996). Van Winkle (1970) had observed

Corresponding author:

J.M.F. Babarro

Email: jbabarro@iim.csic.es that rate of formation and proportion of $M$. edulis forming threads decreased with increasing size. On the contrary, Lee et al. (1990) observed that large Mytilus edulis (30-65 mm) reattached in 'circulating seawater' secreted more threads than smaller mussels $(5-20 \mathrm{~mm})$ although they also reported a reverse effect when detached small individuals of $M$. edulis were exposed to high currents $\left(10-20 \mathrm{~cm} \mathrm{~s}^{-1}\right)$. Eckroat et al. (1993) observed that fewer threads were secreted by small individuals of Dreissena polymorpha than large ones although the range of experimental individual sizes was rather narrow (12 mm and 21-26 mm for both animal sizes, respectively). Individuals of Perna viridis and Septifer virgatus of approximately $20 \mathrm{~mm}$ shell length were observed to secrete more byssal threads than larger individuals of approximately $40 \mathrm{~mm}$ shell length after 24 hours but such a result was not maintained after 60 hours, even the opposite was observed for Perna viridis (Seed \& Richardson, 1999).

Attachment strength of mussels has been measured as tenacity $\left(\mathrm{N} \mathrm{m}^{-2}\right)$ in order to correct the size effect of individuals and, therefore, should not be interpreted as a material property but rather as a size-independent measure of attachment force of individuals (Bell \& Gosline, 1997). Tenacity has been occasionally correlated with the number of threads 
secreted by the mussel Mytilus edulis (Carrington, 2002) and its variability is, therefore, primarily related to byssal threads secreted either based on the number of threads or their thickness, the former accounting for the influence of position on tenacity, i.e. solitary versus bed mussels and the latter accounting for the influence of species (Bell \& Gosline, 1997). Factors most commonly reported to exert significant incidence on tenacity of bivalves are the hydrodynamic forces provoked by currents in nature (Bell \& Gosline, 1997; Hunt \& Scheibling, 2001), predator activity responses (Leonard et al., 1999) or seasonal shifts in energetic resource allocation to vital processes of individuals, i.e. reproduction (Carrington, 2002). The latter energetic factor is of special importance when studying the behaviour of different individuals' sizes because this factor may represent a significant source of variability for endogenous values such as condition and energetic stores both of great importance when animals must cope with stress. It has been hypothesized that bivalves continue to partition energy towards byssal thread formation even when starved (Clarke, 1999), most likely through the transfer of energetic tissue reserves to byssogenesis.

In the present survey, we have investigated the effect of mussel's body size on byssogenesis and attachment strength of Mytilus galloprovincialis maintained in laboratory conditions. For that, two very different sizes were selected as representative of well-differentiated growth stages of mussel culture in Galicia: immature mussel seed of approximately $25 \mathrm{~mm}$ and commercial-size adults of approximately $87 \mathrm{~mm}$ shell length. The latter adult size was selected according to the constraints reported for M. galloprovincialis with regard to absorption efficiency processes of food available (see Pérez Camacho et al., 2000). Mussel culture in Galicia (north-western Spain) is carried out under the raft system and represents a highly significant industry with production values of approximately 250000 tm per year (Pérez Camacho et al., 1995; Labarta, 2004) which in turn is supported by a large amount of mussel seed collected, i.e. 7500 tm per year (Pérez Camacho et al., 1995) before its transportation to the raft. A supplement of a standard laboratory diet (Tahitian Isochrysis aff. galbana, T-ISO + lyophilized sediment) was used to feed animals and simulate mean field values of food availability. The different magnitude of clearance and/or ingestion rates of mussels with large differences in body size was considered in the experimental design to avoid interference of food depletion with the responses of the individuals. The research was planned to investigate the following questions: (i) is byssogenesis rate different between largely differentiated sizes of cultured M. galloprovincialis in Galicia?; (ii) can a significant link be established between byssus secretion and attachment force values in M. galloprovincialis of different sizes?; and (iii) under food availability restrictions, which size is more sensitive considering byssus secretion and attachment force?

\section{MATERIALS AND METHDDS}

\section{Experimental design}

Individuals of Mytilus galloprovincialis were collected in the Ría de Arousa from ropes used for mussel culture on the rafts. Mussels were isolated from the clumps by cutting carefully and individually the byssal threads, classified according to sizeclasses, i.e. juveniles (range: $26-30 \mathrm{~mm}$, mean: $28.8 \pm 1.80 \mathrm{~mm}$ shell length) and large individuals (range: 83-91 mm, mean:
$86.6 \pm 2.83 \mathrm{~mm}$ shell length) and transported to the laboratory. Individuals were placed individually on a glass Petri dish each according to its size and at a certain distance that they cannot attach to each other on the bottom of four 19-litre tanks $(45 \times 40 \times 14 \mathrm{~cm}$, length $\times$ width $\times$ height $)$ and maintained for a week. Glass Petri dishes were selected as substrate based on the capacity to isolate individuals for specific measurements, i.e. absorption efficiency (see below) as well as the fact that has been shown to represent second only to slate surface in mussel's choice of substratum (Young, 1983). Two experiments were run, one (involving four tanks; $\mathrm{N}=48$ individuals) to test the effects of body size and feeding conditions on byssogenesis and attachment strength and the other (involving two tanks; $\mathrm{N}=19-22$ ) to test the relationship between attachment strength and number of byssal threads secreted. Individuals of the different experimental sizes were mixed randomly in each tank to simulate their natural arrangement on the mussel culture rafts. An input flow was distributed into the two series of 19-litre experimental tanks with values of approximately $31 \mathrm{~min}^{-1}$, which in turn represented a flow regime of $0.10 \mathrm{~cm} \mathrm{~s}^{-1}$ through the experimental tanks. The tanks were of open flow design using filtered $(10 \mu \mathrm{m})$ seawater (Cartridge CUNO Super Micro-Wynd $10 \mu \mathrm{m}$ ) with salinity and temperature values of $35.5 \%$ and $13^{\circ} \mathrm{C}$, respectively. The filtered seawater was supplemented with a mixture of microalgae (Tahitian Isochrysis aff. galbana, T-ISO) and sediment from the seafloor below the rafts (40:60 microalgae:sediment, by weight) supplied with a peristaltic pump at constant flow, so that particle load was maintained at $1.2 \mathrm{mg} \mathrm{l}^{-1}$ with an organic content percentage of $50 \%$ simulating the mean values of food availability for the animals in their natural environment of Galician Rías. A rather narrow range of total particulate matter values was observed in situ from the experimental location where mussels were collected in Ría de Arousa (Babarro et al., 2000). After one week of acclimation period, byssal threads were removed carefully by severing threads at the byssal gape with a razor blade and experimental time was considered to begin. During the experimental period, two tanks of the first series of four 19-litre tanks were supplemented with a mixture of food (Tahitian Isochrysis aff. galbana, T-ISO and sediment) following similar patterns of acclimation period whereas the other two tanks were used to test the effect of non-feeding conditions by opening the flow of filtered seawater but without any microalgae base addition.

During both acclimation and experimental periods, orientation of the individuals can be considered to be at random in Petri dishes although if any position is more repetitive that was the dorsal upcurrent to the input flow according to a classification made by Dolmer \& Svane (1994). Nevertheless, neither the latter authors (considering a flow regime range of $\mathrm{o}$ and $7.7 \mathrm{~cm} \mathrm{~s}^{-1}$ ) nor ourselves observed significant effects on number of threads attached relative to the orientation of individuals unless high currents are considered $\approx 19.4 \mathrm{~cm} \mathrm{~s}^{-1}$ in case of the study of Dolmer \& Svane (1994).

\section{Protocol of activities}

\section{QUANTITATIVE VALUES OF BYSSAL THREADS}

\section{SECRETED}

Number of threads produced by the individuals was counted daily in all Petri dishes with a binocular microscope (Nikon SMZ-10 at $4 \times$ ) until asymptotic values were observed. New byssal threads were counted by viewing both upside and 
underside of the mussel through the transparent glass Petri dishes that were clearly visible and new plaques were marked each day on that underside of the dish with permanent ink marker.

\section{ABSORPTION EFFICIENCY (AE), CONDITION INDEX}

\section{AND GLYCOGEN STORES}

Volumes of the experimental diets used to feed the mussels (seawater + T-ISO + sediment; see before) and the faeces produced by fed individuals of different size under study were collected at different sampling times (after 24, 72 and $96 \mathrm{~h}$ ). Faeces were collected from the glass Petri dishes where mussels are located on the bottom of the experimental tanks whereas the experimental diet was collected from the input flow of the system. Both experimental diet and faeces samples were filtered on Whatman GF/C filters and processed for total particulate matter (TPM) and particulate organic matter (POM). Absorption efficiency (AE) was then quantified according to Conover (1966) as follows: $\mathrm{AE}=(\mathrm{F}-\mathrm{E}) /[(1-\mathrm{E}) . \mathrm{F}]$, where $\mathrm{F}$ and $\mathrm{E}$ are the organic content (by weight) of food and faeces, respectively. Due to the fact that $\mathrm{AE}$ values remained rather similar for fed animals during experimental times considered $(P>0.05$ ANOVA), values reported in the present survey represented mean values $( \pm S D)$ of the former sampling times.

Condition index was obtained according to the formula: $\mathrm{CI}=\left(\mathrm{DW}_{\text {tissue }} / \mathrm{DW}_{\text {shell }}\right) \times 100$, where $\mathrm{DW}_{\text {tissue }}$ corresponds to dry weight of soft tissues and $\mathrm{DW}_{\text {shell }}$ to dry weight of the shell (Freeman, 1974). Glycogen was quantified as glucose after precipitation with $100 \%$ ethanol (Strickland \& Parson, 1968). Both condition index and glycogen stores were measured at the beginning of the acclimation period on arrival at the laboratory and after both feeding and non-feeding experimental periods. Table 1 illustrates variability in both condition index values and glycogen stores.

\section{ATTACHMENT STRENGTH AND THREAD'S}

\section{THICKNESS}

Attachment strength was measured as force in Newtons $(1 \mathrm{~kg}=9.81 \mathrm{~N})$ needed to dislodge mussels of both size- classes from substrates used in the present experiment (see before). A steel spring was connected between a firm upper part of a system illustrated in Figure 1, through a screw, and a lower mobile platform, in a way that movement was maintained parallel to the ruler axis (see schematic diagram in Figure 1). A hook in the downside of the mobile platform was linked to an anchorage clamp system where the Petri dish with the mussel is placed. The latter link allowed certain movements of the Petri dish in order to obtain full extension of all byssal threads. Spring extension due to weight of the anchorage system including Petri dish and the animal attached was recorded. A pressure forceps round the attached mussel was connected to a gyratory handle that pulled the nylon thread down (Figure 1). Extension measurements of the spring could be recorded by eye, as a consequence of the extension rate used $\left(60 \mathrm{~mm} \mathrm{~min}^{-1}\right)$ according to the flow that individuals are exposed to in the experimental tanks (see before). The error of the latter estimation represented a variation of $\pm 0.15 \mathrm{~cm}$ (approximately $4 \%$ ). The scale was lifted perpendicular (normal) to the substrate once all byssal threads were observed at full extension until dislodgement occurred. The extension of the spring was calibrated with series of weights and a calibration fit between extension $(\mathrm{cm})$ and weight was obtained (Force $\mathrm{N}=0.4679 \times$ Extension $-0.0015 ; r^{2}=0.999 ; \mathrm{N}=12$ ). Dislodgement force needed to detach mussels of the four 19-litre experimental tanks testing the effect of size and feeding conditions was measured when asymptotic values of byssal threads secreted were obtained at day seven. On the other hand, attachment force of individuals maintained within the second series of two 19-litre experimental tanks was measured daily in different individuals with the aim to obtain a range of both factors threads secreted and attachment force for both experimental mussel sizes.

After measuring the attachment strength of individuals, both shell area of the specimens and byssal thread's thickness were measured by image analysis (IA). IA measurements were performed using the software QWin (C) Leica Imaging Systems) on a PC (AMD Athlon XP $3000+$ ) connected to a video camera (Leica IC A) on a stereo microscope (Leica

Table 1. Values of corporal parameters shell length, dry weight (soft tissues and shell) and condition index (CI) as well as glycogen stores of the experimental individuals at arrival and after feeding and non-feeding periods in the laboratory. Shell area of specimens $\left(\mathrm{cm}^{2}\right)$ and thread's thickness both obtained by image analysis (IA; see Materials and Methods) are also included. Different letters for CI and glycogen values mean significant differences in fed and unfed juvenile mussels.

\begin{tabular}{|c|c|c|c|c|c|c|c|}
\hline & $\begin{array}{l}\text { Shell } \\
\text { length } \\
(\mathrm{mm})\end{array}$ & $\begin{array}{l}\mathrm{DW}_{\text {tissue }} \\
(\mathrm{g})\end{array}$ & $\begin{array}{l}\mathrm{DW}_{\text {shell }} \\
(\mathrm{g})\end{array}$ & $\begin{array}{l}\mathrm{CI} \\
(\%)\end{array}$ & $\begin{array}{l}\text { Glycogen } \\
\text { (\%OM) }\end{array}$ & $\begin{array}{l}\text { Shell area } \\
\text { (IA) }\left(\mathrm{cm}^{2}\right)\end{array}$ & $\begin{array}{l}\text { Thread's } \\
\text { thickness } \\
\text { (IA) (mm) }\end{array}$ \\
\hline \multicolumn{8}{|l|}{ Small size } \\
\hline Arrival & $\begin{array}{l}26.4 \pm 0.9 \\
\quad(10)\end{array}$ & $\begin{array}{c}0.13 \pm 0.02 \\
(10)\end{array}$ & $\begin{array}{c}0.58 \pm 0.10 \\
(10)\end{array}$ & $\begin{array}{c}22.0 \pm 2.3^{a} \\
(10)\end{array}$ & $\begin{array}{c}10.12 \pm 1.30^{\mathrm{a}} \\
(10)\end{array}$ & & \\
\hline Fed & $\begin{array}{l}29.4 \pm 1.9 \\
\quad(12)\end{array}$ & $\begin{array}{c}0.21 \pm 0.06 \\
(12)\end{array}$ & $\begin{array}{c}0.83 \pm 0.05 \\
\quad(12)\end{array}$ & $\begin{array}{c}25.8 \pm 3.7^{\mathrm{b}} \\
(12)\end{array}$ & $\begin{array}{c}8.95 \pm 1.44^{\mathrm{a}} \\
(12)\end{array}$ & $\begin{array}{c}4.56 \pm 0.31 \\
(12)\end{array}$ & $0.067 \underset{(36)}{ \pm} 0.002$ \\
\hline Unfed & $\begin{array}{l}28.2 \pm 1.5 \\
\quad(12)\end{array}$ & $\begin{array}{c}0.14 \pm 0.03 \\
(12)\end{array}$ & $\begin{array}{c}0.83 \pm 0.10 \\
(12)\end{array}$ & $\begin{array}{c}17.7 \pm 3.1^{\mathrm{c}} \\
(12)\end{array}$ & $\begin{array}{c}7.05 \pm 0.69^{b} \\
(12)\end{array}$ & $\begin{array}{c}4.23 \pm 0.41 \\
(12)\end{array}$ & \\
\hline \multicolumn{8}{|l|}{ Large size } \\
\hline Arrival & $\begin{array}{c}83.2 \pm 3.6 \\
(10)\end{array}$ & $\begin{array}{c}3.60 \pm 0.50 \\
(10)\end{array}$ & $\begin{array}{c}10.31 \pm 1.51 \\
\quad(10)\end{array}$ & $\begin{array}{l}34.8 \pm 2.0 \\
(10)\end{array}$ & $\begin{array}{l}21.47 \pm 5.2 \\
\quad(10)\end{array}$ & & \\
\hline Fed & $\begin{array}{l}87.1 \pm 2.3 \\
\quad(12)\end{array}$ & $\begin{array}{c}3.99 \pm 0.76 \\
(12)\end{array}$ & $\begin{array}{c}12.61 \pm 1.32 \\
\quad(12)\end{array}$ & $\begin{array}{l}33.6 \pm 4.2 \\
\quad(12)\end{array}$ & $\begin{array}{l}18.25 \pm 4.8 \\
\quad(12)\end{array}$ & $\begin{array}{c}27.63 \pm 1.41 \\
\quad(12)\end{array}$ & $\begin{array}{c}0.193 \pm 0.049 \\
(36)\end{array}$ \\
\hline Unfed & $\begin{array}{l}86.1 \pm 3.7 \\
\quad(12)\end{array}$ & $\begin{array}{c}4.10 \pm 0.61 \\
(12)\end{array}$ & $\begin{array}{c}12.70 \pm 1.31 \\
\quad(12)\end{array}$ & $\begin{array}{l}33.5 \pm 3.4 \\
\quad(12)\end{array}$ & $\begin{array}{c}18.03 \pm 4.6 \\
\quad(12)\end{array}$ & $\begin{array}{l}28.57 \pm 1.93 \\
\quad(12)\end{array}$ & \\
\hline
\end{tabular}




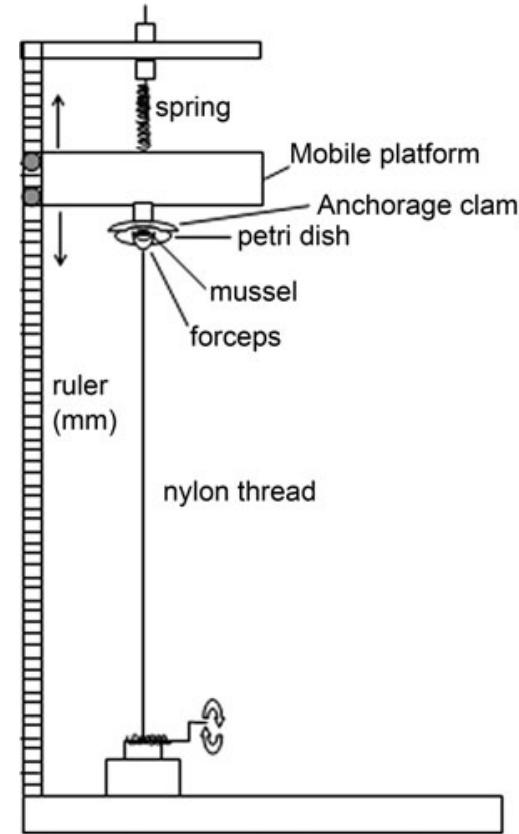

Fig. 1. Schematic diagram of the attachment force recorder used in the laboratory (see Materials and Methods for detailed explanation).

MZ6). Camera and light settings were established at the beginning of the analysis and kept constant throughout the whole analysis. Tenacity was then calculated as the dislodgement force divided by shell area of individuals $\left(\mathrm{N} \mathrm{m}^{-2}\right)$. Byssal thread's thickness was recorded by IA in both experimental sizes of fed individuals (Table 1). The latter thread's thickness values referred to the distal region of the thread that remained attached to the Petri dish after dislodgement of individuals due to the fact that location of the structural failure was approximately $100 \%$ in the proximal region (see also Bell \& Gosline, 1996).

\section{Statistical analysis}

Numbers of byssal threads produced by the mussels daily were compared by means of ANOVA in the different treatments with the aim of observing differences also by the cumulative experimental time. Cumulative values of threads are presented as the mean \pm standard deviations of twelve individuals in each experimental tank. One-way ANOVA was also used to compare absorption efficiency, byssogenesis rate and thread's thickness values between fed animals of different size as well as for the variability of condition index and glycogen store values. Three-way ANOVA was used to test the effect of mussel size (fixed, small versus large individuals), feeding (fixed, fed versus unfed animals) and the hypothetical effect of the tank itself (random) on attachment strength of individuals as force log transformed values. Individuals that formed none or only one thread represented a number of six mussels in the whole population $(\mathrm{N}=48)$, two and four individuals from the fed and unfed experimental groups, respectively. The latter six values were removed from the three-way ANOVA because of difficulties obtaining reliable dislodgement force values. With our experimental design, the importance of interactions, i.e. size* feeding or size*tank were also tested in the three-way ANOVA. Homogeneous groups among experimental mussels could be established $a$ posteriori by using Tukey's test. When variances were not homogeneous (Levene's test), non-parametric KolmogorovSmirnov and Mann-Whitney tests were used. To test the relationship between attachment strength and number of byssus threads secreted regression analysis was used. For all analyses performed statistical computer packages STATISTICA 6.0 and SPSS 14.0 were used.

\section{RESULTS}

\section{Body size parameters, condition index and glycogen stores}

Table 1 illustrates a number of corporal parameters, i.e. shell length, weight values of soft tissues and shell, condition indices, area of the shell as well as glycogen store values of individuals during the experimental time. Condition index (CI) values of mussels at arrival in the laboratory were $\mathbf{2 2 . 0 \%}$ and $34.8 \%$ for juveniles and larger mussels, respectively $(P<0.001$ ANOVA; Table 1$)$. Remarkably, CI remained unchanged in large fed individuals and slightly increased in juveniles (from 22.0 to 25.8\%; $P<0.05$ ANOVA) under laboratory feeding conditions. However, juveniles maintained unfed for a week with filtered seawater showed a significant drop in CI from 25.8 to $17.7 \%(P<0.01$ ANOVA; Table 1$)$ whereas large mussels kept $C I$ values unchanged $(P>0.05$ ANOVA) approximately in values of $33 \%$ of dry soft tissues throughout the experimental period (Table 1).

Similarly to CI values, glycogen did not show any significant change in large mussels either with the experimental time of control fed animals or when subjected to non-feeding conditions $(P>0.05$ ANOVA; Table 1$)$, values ranging between $18-21 \%$ of organic matter. However, juveniles maintained unfed showed a significant decrease in glycogen stores of approximately $21 \%$ with regard to control fed animals (from 8.9 to $7.0 \%$ of organic matter; $P<0.01$ ANOVA; Table 1 ). Glycogen values of large mussels were approximately 2-2.6-fold higher than in juveniles throughout the whole experiment (Table 1). Remarkably, variability reported for mean glycogen values was much higher in large mussels (2-fold) than in juveniles with regard to standard deviations obtained. Shell area values of the individuals kept under feeding conditions varied between $4.2-4.6 \mathrm{~cm}^{2}$ and $27.6-$ $28.6 \mathrm{~cm}^{2}$ for juveniles and larger mussels, respectively (Table 1 ).

\section{Byssogenesis}

Cumulative number of threads produced by control fed individuals of both experimental sizes is illustrated in Figure 2A. Juveniles secreted a significantly higher number of byssal threads from the 2 nd day $(28 \pm 3.7$ and $18 \pm 3.1$ in small and large mussels, respectively; ANOVA $P<0.05$ ) onwards, up to a range of 42-46 (juveniles) and 27-31 (large mussels) byssal threads during the rest of experimental time (ANOVA $P<0.05$; Figure 2A). Asymptotic values of thread's number attached to the substratum were reached between the 3 rd and $4^{\text {th }}$ day in both mussel sizes. Remarkable was the fact observed during the experimental period that small individuals were much more active than 

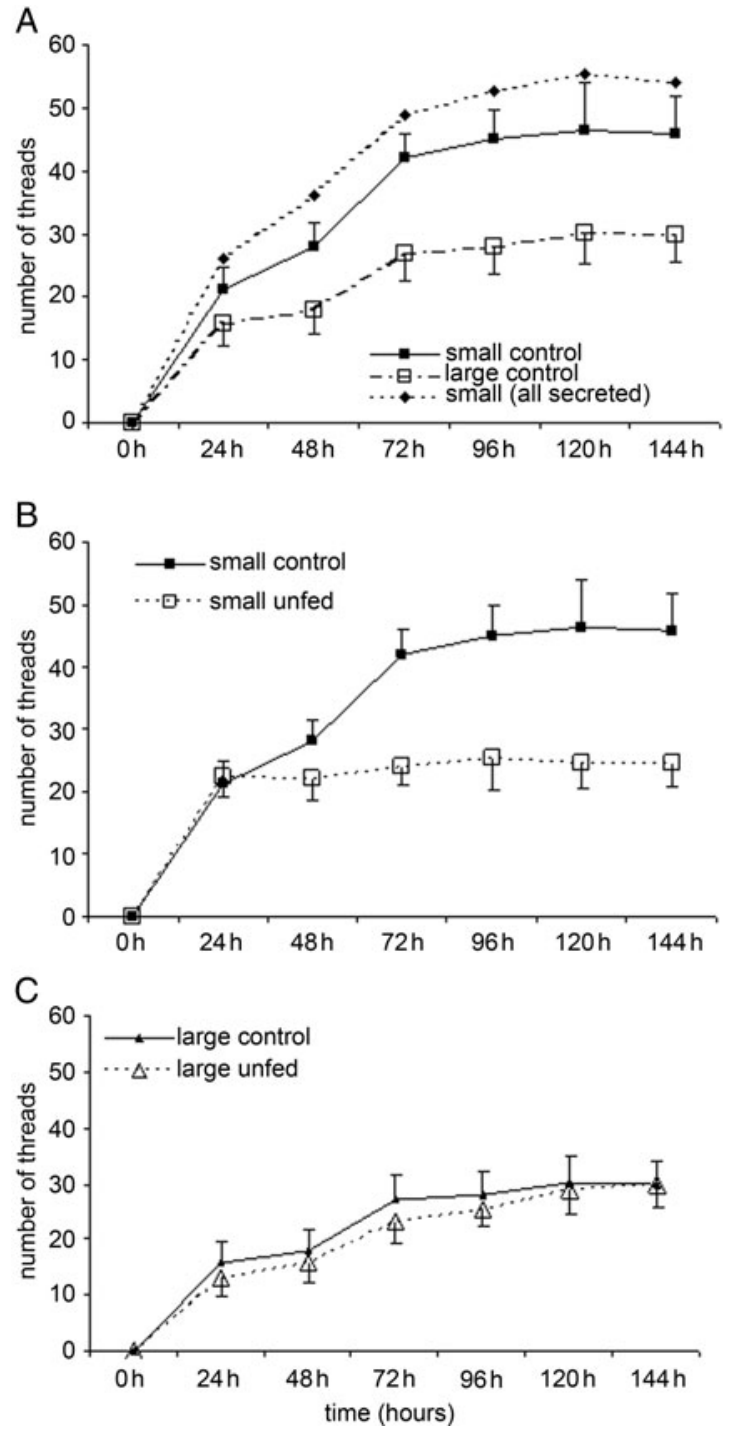

Fig. 2. Byssal threads secretion (mean values $\pm S E$ ) of control fed juveniles and large mussels (A), control fed and unfed juveniles (B) and, control fed and unfed large mussels (C) during the experimental time. The sum of attached and non-attached threads secreted by fed juveniles is included in (A) to highlight their mobility (see text).

larger individuals at the beginning of the experiment, searching for different locations before permanent attachment. As a consequence of the latter activity, actual number of byssal threads secreted was approximately $21 \%$ higher than the number of threads attached to the substratum (Figure $2 \mathrm{~A}$ ).

Maintenance of individuals under non-feeding conditions for a week caused no significant effect on byssogenesis of larger mussels $(P>0.05$; Figure $2 \mathrm{C}$ ) but reduced significantly the number of threads secreted in juveniles by a factor of approximately 43\% (ANOVA, $P<0.05$; Figure 2B) from 72 hours of the experiment onwards. Differences in byssal secretion of non-feeding juveniles also referred to the time at which asymptotic values were reached ( 24 hours) when compared to fed individuals ( 72 hours) (Figure $2 \mathrm{~B}$ ).

Byssal thread's thickness at the distal region obtained by IA of the byssus secreted by fed individuals of both sizes represented values of $0.067 \pm 0.002$ and $0.193 \pm 0.049 \mathrm{~mm}$ for juveniles and large mussels, respectively $(P<0.001$ ANOVA; Table 1).

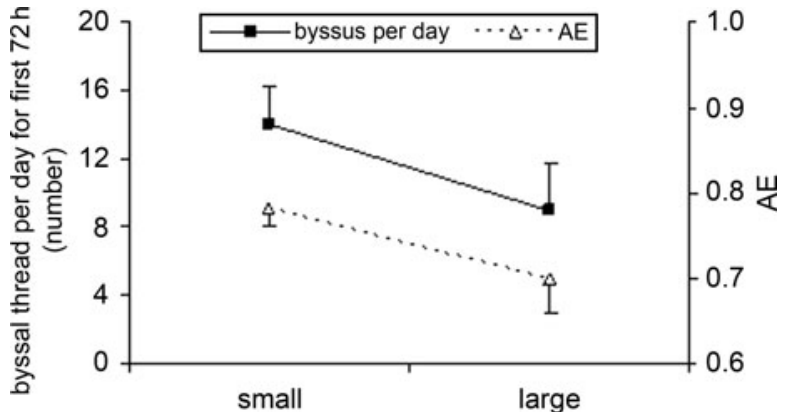

Fig. 3. Absorption efficiency values (AE) and byssogenesis rate (for first 72 experimental hours) of control fed juvenile and large mussels. AE referred to mean values obtained for different sampling times during feeding of individuals (after 24, 72 and 96 hours).

\section{Absorption efficiency (AE)}

Figure 3 illustrates differences in both absorption efficiency values (AE) and byssogenesis rates of control fed small and larger individuals. Byssogenesis rates referred to the number of threads secreted per day during the first 72 hours, time at which asymptotic values of byssogenesis were reached for both mussel sizes (Figure 2A). AE was significantly higher in juveniles $(78 \%)$ as compared to larger mussels $(70 \%)(P<0.001$ ANOVA) as well as byssogenesis rates that were reduced in approximately $36 \%$ in larger fed mussels as compared to juveniles for the first 72 hours (Figure 3 ).

\section{Attachment strength}

The strength of byssal attachment was measured as the force needed to detach the mussels from the substratum and considering the number of byssal threads actually attached at the end of the experiment (asymptotic values
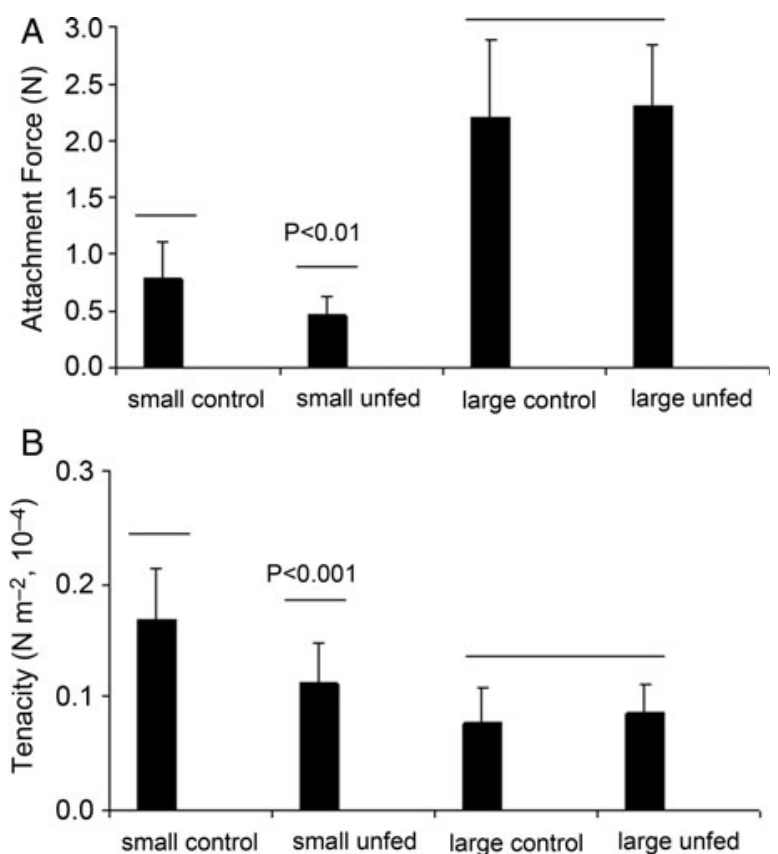

Fig. 4. Attachment strength as force (Newtons $\mathrm{N} ; \mathrm{A})$ and tenacity $\left(\mathrm{N} \mathrm{m}^{-2} ; \mathrm{B}\right)$ values for juveniles and large mussels maintained under feeding and non-feeding conditions at the laboratory. Bars at different level mean significant differences. 
of byssus). Figure 4 illustrates both force and tenacity values with regard to different size of mussels and feeding conditions. Three-way ANOVA was used to test attachment strength variability (log transformed force) as function of fixed factors mussel size and feeding conditions as well as the random factor tank (see Materials and Methods; Table 2). Attachment force was significantly affected by mussel size $(P<0.001)$ and the interaction term of 'size*feeding' $(P<0.05)$ as indicative of the fact that absence of microalgae supplementation in the seawater caused a reduction in attachment force of individuals but only in the case of juveniles. Tank factor (itself or in a number of interactions, see Materials and Methods), however, did not show any significant effect on the attachment force values obtained in the experiment $(P>0.05$; Table 2). Average force values required to detach small fed mussels were $0.78 \mathrm{~N}$ whereas a 2.8 -fold increase was needed to dislodge larger fed individuals $(2.21 \mathrm{~N}$; Figure 4A). Maintenance of individuals under non-feeding conditions caused a reduction in attachment force of approximately $41 \%$ in juveniles $(P<0.05$ ANOVA $)$ but no significant differences were reported for larger mussels $(P>0.05$ ANOVA; Figure 4A) under such stressful conditions.

With regard to tenacity differences between mussel sizes, a reverse pattern than that of attachment force was observed. Tenacity values of fed small mussels were 2.2 times higher than larger specimens (0.17 versus $0.08 \mathrm{~N} \mathrm{~m}^{-2} \cdot 10^{-4}$; Figure $4 \mathrm{~B} ; \quad P<0.05$ ANOVA). Similarly to attachment force, tenacity of small mussels significantly dropped from 0.17 to $0.11 \mathrm{~N} \mathrm{~m}^{-2} \cdot 10^{-4}(P<0.05$ ANOVA $)$ when maintained unfed for a week whereas larger mussels did not show any significant variation with values of approximately $0.080 \mathrm{~N} \mathrm{~m}^{-2} \cdot 10^{-4}$ for both control and unfed individuals $(P>0.05$ ANOVA; Figure $4 \mathrm{~B})$.

Considering the second series of the two 19-litre tanks (see Materials and Methods), a significant relationship between attachment force values of the individuals and the quantitative values of byssus were obtained for both experimental sizes (Figure 5). Linear fits for the latter relationships attachment force versus byssal threads represented in Figure 5 corresponded to the following equations:

Table 2. Three-way ANOVA on logarithmic transformed values of attachment force as a function of mussel size (fixed factor: large versus small mussels), feeding condition (fixed factor: control fed versus unfed mussels) and considering the tank as random factor (see Materials and Methods).

\begin{tabular}{lrlcl}
\hline $\begin{array}{l}\text { Dependent variable: } \\
\text { attachment force }(\mathbf{l o g})\end{array}$ & df & MS & F & $\boldsymbol{P}$ \\
\hline Source & & & & \\
intercept & 1 & 0.0503 & 0.9753 & NS \\
size & 1 & 3.8166 & 74.0678 & $P<0.000$ \\
feeding & 1 & 0.0424 & 0.8335 & NS \\
tank & 3 & 0.0173 & 0.336 & NS \\
size feeding & 1 & 0.2405 & 4.6681 & $P<0.05$ \\
size*tank & 3 & 0.0318 & 0.6166 & NS \\
tank*feeding & 3 & 0.0007 & 0.0127 & NS \\
size*feeding*tank & 3 & 0.0650 & 1.2611 & NS \\
error & 26 & 0.0515 & & \\
\hline
\end{tabular}

$\mathrm{r}=0.881 ; \mathrm{N}=42 ; P<0.001$

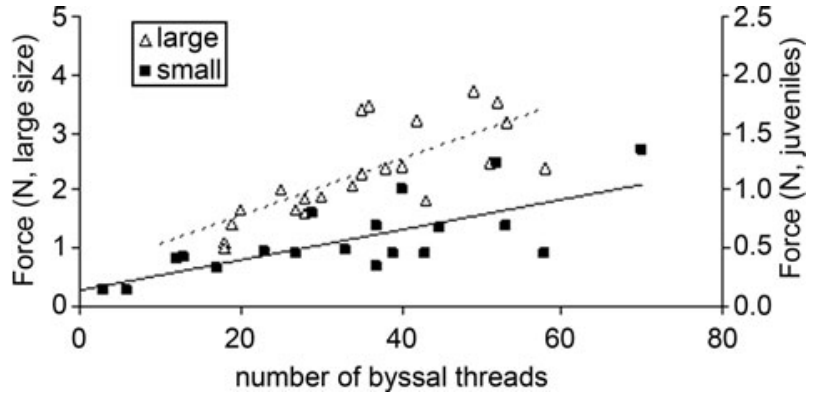

Fig. 5. Relationship between attachment force and number of byssal threads secreted by individuals of both experimental sizes. Equations that corresponded to the linear fits shown in the Figure are reported in the main text (see Results section). Note different scaling of $\mathrm{Y}$ axis for juveniles $(0-2.5 \mathrm{~N})$ and large mussels $(0-5 \mathrm{~N})$.

$$
\begin{aligned}
\text { Small size:Force }= & 0.139+0.013 \pm 0.003 \times \text { threads } \\
& \text { number } \\
& \mathrm{N}=19, \mathrm{r}=0.73, P<0.001 \\
\text { Large size:Force }= & 0.584+0.048 \pm 0.010 \times \text { threads } \\
& \text { number } \\
& \mathrm{N}=22, \mathrm{r}=0.73, P<0.001
\end{aligned}
$$

\section{DISCUSSIDN}

Results of the present study highlighted a significantly higher byssal secretion in juveniles of $M$. galloprovincialis than in larger specimens under laboratory flowing calm waters. This pattern appeared to be significant from the 2 nd experimental day onwards whereas asymptotic number of threads attached to the substrate varied between $42-46$ and $27-31$ threads in juveniles and large mussels, respectively (Figure 2A). A lower byssal thread secretion in larger specimens of Mytilus edulis and Geukensia demissa was also reported in different studies (Van Winkle, 1970; Allen et al., 1976; Lee et al., 1990). Other surveys that presented mussel's body size effect on byssogenesis rate were not conclusive enough due to rather narrow experimental size-ranges (Eckroat et al., 1993) or a change in the secretion patterns during the experimental time (Seed \& Richardson, 1999; see Introduction). It is important to note that in case of the study of Lee et al. (1990), such inverse relationship of byssogenesis versus size of individuals was observed only when mussels faced high currents $\left(10-20 \mathrm{~cm} \mathrm{~s}^{-1}\right)$ whereas a higher secretion of threads in larger M. edulis $(30-65 \mathrm{~mm})$ was reported when subjected to 'circulating seawater' as compared to small individuals $(5-20 \mathrm{~mm})$. The latter authors argued that a higher mobility of small individuals might be the basis for their lower threads secretion 'leading to shorter attachment lives for individual byssal threads'. We have also observed a higher mobility of juveniles in the present study as well as the fact that occasionally individuals left the stem and fewer threads behind, looking for another location in the Petri dish (see also Bell \& Gosline, 1997). Accordingly, differences in byssogenesis of both experimental sizes presented here would be even more abrupt in case all threads secreted are considered $(21 \%$ increase; Figure 2A). As was the case of Lee et al. (1990), in the present study only those operative threads attached to the substrate were considered. 
Higher byssogenesis for juvenile mussels might be related to the fact that smaller and lighter specimens would be more susceptible to being swept away facing environmental currents in nature, therefore, suffering a higher risk of dislodgement (Lee et al., 1990). Results presented here showed that such higher potential to secrete threads in juveniles was significant even when exposed to calm flow regimes in the laboratory (see Materials and Methods), i.e. there is no urgent need to re-attach with a high number of threads. A range of flow velocity between o (still waters) and $7.7 \mathrm{~cm} \mathrm{~s}^{-1}$ was identified to show no effect on number of byssal threads secreted by Mytilus edulis in the laboratory (Dolmer \& Svane, 1994) and therefore, differences in byssogenesis reported here might correspond to intrinsic mechanisms of individuals to attach themselves to substrate.

On one hand, constraints for the byssal threads secretion in large specimens might derive from energy absorption processes reported for both mussel sizes. Indeed, absorption efficiency values showed a significant drop in larger mussels as compared to juveniles (Figure 3 ) that would indicate a lower potential to assimilate energy from the available food. Generally, absorption efficiency of mussels has been described as independent of size for different species, i.e. Mytilus edulis (Vahl, 1973), Mytilus chilensis (Navarro \& Winter, 1982) and Modiolus modiolus (Winter, 1978). However, specifically for Mytilus galloprovincialis, Pérez Camacho et al. (2000) have reported a critical length of $85 \mathrm{~mm}$ 'above which the ageing of the mussel becomes evident'. Larger specimens selected for the present study fit in such critical body size for absorption efficiency maintenance. On the other hand, it is also important to note that mature mussels like the larger size individuals considered in the present study may allocate as much as $90 \%$ of their total production to gamete synthesis (Seed \& Suchanek, 1992) which in turn would mean that the reduced investment in byssal thread secretion can be considered as means by which an individual channels energy into reproductive effort (Carrington, 2002), specially when individuals have to deal with soft hydrodynamic loads. Such constraints concerning the reproduction tissue allocation would not limit the investment of energy into byssogenesis in case of immature juveniles in the present study.

The fact that either metabolic efficiency constraints and/or energy allocation differences in both experimental size/age of the mussels used here might interfere with byssogenesis rates needs more research. Preliminary results considering mussels originally from two very different environments, i.e. intertidal and subtidal Mytilus galloprovincialis of similar and significantly different condition index values, respectively, corroborated an inverse relationship between byssogenesis and mussel size as well as between absorption efficiency and size of intertidal individuals. However, such inverse relationship was found to be not significant in subtidal individuals most likely as a consequence of differences in conditioning values of the mussels that would mask the actual effect of size (Babarro et al., 2005).

Attachment strength was significantly correlated with number of byssal threads secreted by the individuals (Figure 5) and would point to byssus as the primary mechanism for attachment strength variability regardless of mussel size. Indeed, number of threads has been also reported to account for much of the observed variability in tenacity of solitary versus bed mussels (Bell \& Gosline, 1997) although
Dolmer \& Svane (1994) had also highlighted that this correlation would be not a simple function but rather influenced by flow velocity and drag. Current velocity of seawater has been reported to be a crucial environmental parameter when studying attachment strength of mussels exposed to rocky shore environments (Price, 1982; Hunt \& Scheibling, 2001) but neither the present environmental scenario where mussels were collected from rafts in sheltered Galician Rías (north-western Spain; Pérez Camacho et al., 1995) nor the actual experimental conditions in laboratory as well as the randomly orientated individuals in the Petri dishes (see Materials and Methods) can be considered as important effectors (if any) on our data. In this sense, a random situation of both individual sizes within each experimental tank was considered important in the experimental design in order to avoid differences between independent inflows of the system and simulate, at the same time, a similar space that has to be shared by different sizes in nature.

Differences in size of the experimental mussels made necessary, however, to consider thread thickness in the analysis of attachment strength data (see Table 1). Attachment force of fed large individuals was 2.8 times higher than fed juveniles (2.2 vs $0.78 \mathrm{~N}$, respectively; Figure $4 \mathrm{~A}$ ), despite their lower number of byssal threads secreted (Figure $2 \mathrm{~A}$ ). Interestingly, such differences were of the same magnitude to thread's thickness values (2.8 times thicker threads in large mussels; see Table 1) which would suggest such a factor as significant to explain differences in attachment force between sizes. First of all, attachment force values of Mytilus galloprovincialis were of similar magnitude to those reported by Lee et al. (1990) for Mytilus edulis of similar size-classes, considering an average number of threads secreted by the individuals and despite strong differences in flow current used by Lee et al. $\left(10-20 \mathrm{~cm} \mathrm{~s}^{-1}\right)$ and our study. More recently, Reimer \& Harms-Ringdahl (2001) have also reported values of attachment strength of $0.6 \mathrm{~N}$ for North Sea Mytilus edulis within the size-range of 10-30 $\mathrm{mm}$ and Dolmer \& Svane (1994) obtained attachment strength values of approximately $2.5 \mathrm{~N}$ (from their figure 3) for Mytilus edulis within the range of 64-88 mm shell length. Secondly, a reverse pattern for attachment strength considering force and tenacity values resulted in significantly higher tenacity for juveniles (Figure ${ }_{4} \mathrm{~B}$ ). The latter result might be based, in one hand, on higher byssogenesis rates of juveniles that would also determine higher tenacity according to linear relationships between both variables (Bell \& Gosline, 1997; Carrington, 2002) but also the fact that whereas attachment force increased by a factor of 2.8 times in large individuals compared to juveniles, the specimen's shell area exposed to the flow increased by a factor of 6 times for the same size comparison (see Table 1).

The significant effects observed in mussels after nonfeeding maintenance period were restricted to juveniles. Both byssogenesis and attachment force dropped significantly $(41-43 \%$; Figures $2 \mathrm{~B}, 4 \mathrm{~A}-\mathrm{B})$ in unfed juveniles as compared to control fed individuals. Simultaneously, condition values and glycogen stores were also significantly reduced in unfed juveniles (Table 1) which in turn might be the basis of the former drop in byssus secretion/attachment force according to the transfer of energy to byssus formation from soft tissues under stress (Clarke, 1999). The latter author has suggested such a transfer factor between byssus and soft tissues to be a constant function based on similar ratio values of organic carbon between both byssus and soft 
tissues across several feeding levels including starvation (approximately $2 \%$ for Dreissena polymorpha). Surprisingly, large mussels did not show any significant variation in both byssus secretion and attachment force when unfed (Figures ${ }_{2} \mathrm{C}, 4$ ) but neither condition index nor glycogen stores were significantly affected (Table 1 ) despite the fact that, in the case of glycogen, the variability observed was also significantly high. The latter result cannot be completely addressed with the present experimental design since one might have expected that energy to support similar byssus formation rates, once asymptotic values are reached (Figure $2 \mathrm{C}$ ) after maintenance of individuals unfed would derive from endogenous reserves, i.e. glycogen stores. Metabolic requirements for byssus formation may represent up to $10 \%$ of mussel's monthly energy expenditure (Jordan \& Valiela, 1982; Hawkins \& Bayne, 1985) but differences in endogenous values of the individuals (energetic status) facing feeding stress may also play a role on their responses. On one hand, condition and glycogen stores was significantly higher in large mussels than in juveniles throughout the whole experimental period (1.3-1.9 and 2.0-2.6-fold higher in both condition and glycogen stores, respectively; Table 1) which greatly differentiate both sizes in terms of reproductive stage and nutritional status to face stress. Most likely, a week of nonfeeding maintenance conditions was insufficient to observe any pattern of variation in byssus secretion and attachment strength of large mussels with higher nutritional reserves despite the fact that individuals have already reached their asymptotic secretion values.

In summary, it can be highlighted that byssus secretion was significantly higher in juveniles of $M$. galloprovincialis as compared to larger individuals under control feeding conditions. Metabolic constraints represented here by absorption efficiency values reported for both experimental sizes might be on the basis of such results. Attachment force was linearly correlated with the number of threads secreted by the individuals of both sizes but a higher byssogenesis rate of juveniles together with a lower increase in ratio of the attachment strength values in the comparison large versus juveniles (2.8 times) as compared to the increased ratio in shell area (6 times) for the same comparison, caused tenacity of individuals to be also significantly higher in juveniles. Maintenance of juveniles under non-feeding conditions caused a significant decrease in byssus secretion and attachment force as a consequence of the soft tissues/glycogen stores drop suggesting a constant ratio between both soft tissues and byssus under stress.

\section{ACKNDWLEDGEMENTS}

We would like to thank E. Silva, B. González, L. Nieto and A. Ayala for technical assistance. We also greatly thank R. Filgueira and L. Peteiro for attachment force measurements. Results of the present study were supported by the Project AGL2006-06986/ACU (Ministerio de Educación y Ciencia, Plan Nacional de Investigación Científica, Desarrollo e Innovación Tecnológica 2004-2007).

\section{REFERENCES}

Allen J.A., Cook M., Jackson D.J., Preston S. and Worth E.M. (1976) Observations on the rate of production and mechanical properties of the byssus threads of Mytilus edulis L. Journal of Molluscan Studies $42,279-289$.

Babarro J.M.F., Fernández-Reiriz M.J. and Labarta U. (2000) Growth of seed mussel (Mytilus galloprovincialis Lmk): effects of environmental parameters and seed origin. Journal of Shellfish Research 19, 187-193.

Babarro J.M.F., Fernández-Reiriz M.J. and Labarta U. (2005) Byssogenesis of the mussel Mytilus galloprovincialis as a function of body size. Effects of starvation under laboratory conditions. In ASLO Summer Meeting (American Society of Limnology and Oceanography): Conference Abstracts, Santiago de Compostela (Spain), 19-24 June 2005, p. 11.

Bell E.C. and Gosline J.M. (1996) Mechanical design of mussel byssus: material yield enhances attachment strength. Journal of Experimental Biology 199, 1005-1017.

Bell E.C. and Gosline J.M. (1997) Strategies for life in flow: tenacity, morphometry, and probability of dislogement of two Mytilus species. Marine Ecology Progress Series 159, 197-208.

Carrington E. (2002) Seasonal variation in the attachment strength of blue mussels: causes and consequences. Limnology and Oceanography 47, 1723-1733.

Clarke M. (1999) The effect of food availability on byssogenesis by the zebra mussel (Dreissena polymorpha Pallas). Journal of Molluscan Studies 65, 327-333.

Clarke M. and McMahon R.F. (1996) Comparison of byssal attachment in Dreissenid and Mytilid mussels: mechanisms, morphology, secretion, biochemistry, mechanisms and environmental influences. Malacological Reviews 29, 1-16.

Conover R.J. (1966) Assimilation of organic matter by zooplankton. Limnology and Oceanography 11, 338-354.

Dolmer P. and Svane I. (1994) Attachment and orientation of Mytilus edulis L. in flowing water. Ophelia 40, 63-74.

Eckroat L.R., Masteller E.C., Shaffer J.C. and Steel L.M. (1993) The byssus of the zebra mussel (Dreissena polymorpha): morphology, byssal thread formation, and detattachment. In Nalepa, T.F. and Schoesser D.W. (eds) Zebra mussels: biology, impact, and control. Boca Raton, Florida: Lewis Publishers, pp. 239-263.

Freeman KR. (1974) Growth, mortality and seasonal cycle of Mytilus edulis in two Nova Scotian embayments. Department of the Environment, Fisheries and Marine Service, Canada, Technical Report No. 500, p. 112.

Hawkins A.J.S. and Bayne B.L. (1985) Seasonal variation in the relative utilization of carbon and nitrogen by the mussel Mytilus edulis: budgets, conversion efficiencies and maintenance requirements. Marine Ecology Progress Series 25, 181-188.

Hunt H. and Scheibling R.E. (2001) Predicting wave dislodgement of mussels: variation in attachment strength with body size, habitat, and season. Marine Ecology Progress Series 213, 157-164.

Jordan T.E. and Valiela I. (1982) A nitrogen budget of the ribbed mussel, Geukensia demissa, and its significance in nitrogen flow in a New England salt marsh. Limnology and Oceanography 27, 75-90.

Labarta U. (2004) El mejillón, un paradigma bioeconómico. In Labarta U., Fernández Reiriz M.J., Pérez Camacho A. and Pérez Corbacho E. (eds) Bateeiros, mar, mejillón. Una perspective bioeconómica. Colección: Monografías. Serie: Estudios Sectoriales, Fundación CaixaGalicia, pp. $19-47$.

Lee C.Y., Shirley S.L. and Owen M.D. (1990) The rate and strength of byssal reattachment by blue mussels (Mytilus edulis L.). Canadian Journal of Zoology 68, 2005-2009. 
Leonard G.H., Bertness M.D. and Yund P.O. (1999) Crab predation, waterborne cues, and inducible defenses in the blue mussel, M. edulis. Ecology 80, 1-14.

Martella T. (1974) Some factors influencing byssus thread production in Mytilus edulis (Mollusca: Bivalvia) Linnaeus, 1758. Water, Air and Soil Pollution 3, 171-177.

Navarro J.M. and Winter J.E. (1982) Ingestion rate, assimilation efficiency and energy balance in Mytilus chilensis in relation to body size and different algal concentration. Marine Biology 67, 255-266.

Pérez Camacho A., Labarta U. and Beiras R. (1995) Growth of mussels (Mytilus edulis galloprovincialis) on cultivation rafts: influence of seed source, cultivation site and phytoplankton availability. Aquaculture $138,349-362$.

Pérez Camacho A., Labarta U. and Navarro E. (2000) Energy balance of mussels Mytilus galloprovincialis: the effect of length and age. Marine Ecology Progress Series 199, 149-158.

Price H.A. (1982) An analysis of factors determining seasonal variation in the byssal attachment strength of Mytilus edulis L. Journal of the Marine Biological Association of the United Kingdom 62, 147-155.

Reimer O. and Harms-Ringdahl S. (2001) Predator-inducible changes in blue mussels from the predator-free Baltic Sea. Marine Biology 139, 959-965 (DOI 10.1007/s002270100606).

Seed R. and Suchanek T.H. (1992) Population and community ecology of Mytilus. In Gosling E.G. (ed.) The mussel Mytilus: ecology, physiology, genetics, and culture. Amsterdam: Elsevier, pp. 87-169.

Seed R. and Richardson C.A. (1999) Evolutionary traits in Perna viridis (Linnaeus) and Septifer virgatus (Wiegmann) (Bivalvia: Mytilidae). Journal of Experimental Marine Biology and Ecology 239, 273-287.
Strickland J.D. and Parson T.R. (1968) A practical handbook of sea water analysis. Bulletin of the Fisheries Research Board of Canada 167, $173-174$.

Van Winkle W. (1970) Effect of environmental factors on byssal thread formation. Marine Biology (Berlin) 7, 143-148.

Vahl O. (1973) Pumping and oxygen consumption rates of Mytilus edulis L. of different sizes. Ophelia 12, 45-51.

Widdows J. and Bayne B.L. (1971) Temperature acclimation of Mytilus edulis with reference to its energy budget. Journal of the Marine Biological Association of the United Kingdom 51, 827-843.

Winter J.E. (1978) A review of the knowledge of suspension feeding in lamellibranchiate bivalves, with special reference to artificial aquaculture systems. Aquaculture 13, 1-33.

Young G.A. (1983) Response to and selection between, firm substrata by Mytilus edulis. Journal of the Marine Biological Association of the United Kingdom 63, 653-659.

and

Young G.A. (1985) Byssus-thread formation by the mussel Mytilus edulis: effects of environmental factors. Marine Ecology Progress Series 24, $261-271$.

\section{Correspondence should be addressed to:} Jose M.F. Babarro Instituto de Investigaciones Marinas CSIC Eduardo Cabello 6, 36208 Vigo, Spain email: jbabarro@iim.csic.es 